UDC: $378.6: 37.012$

DOI: https://doi.org/10.24195/2414-4665-2017-8-18

\author{
Nataliia Kostova, \\ PhD (Candidate of Legal Sciences), associate professor, \\ Department of Civil Law, \\ National University "Odesa Law Academy”, \\ 5, Academichna Str., Odesa, Ukraine
}

\title{
STRUCTURAL MODEL OF STUDENTS-FUTURE LAWYERS' PROFESSIONAL COMPETENCE
}

The paper aims to present a designed factorial and criterial model of lawyer's professional competence. The research is based on factorial and criterial modelling method, Delphi method, and methods of mathematical statistics. It has been found that the occupation of a lawyer is characterized by systematicity, dynamism, value orientations, responsibility, the ability to perform professional duties properly. Professional competence of a lawyer has a three-level hierarchical structure: the first level is composed of key competences: civil, social, purposeful development, general cultural, responsibility; the second one involves general competences: legal, administrative, functional, communicative, educational, and scientific; the third level is presented by special professional competences: special theoretical and special functional competences. Based on qualimetric approach there has been designed a model of lawyer's professional competence, where the levels and kinds of competences are defined by factors and criteria. The weight coefficients for every factor and criterion have been calculated. The peculiarity of this model is the possibility of adapting it to the specificity of any kind of legal activities which provides its flexibility.

Keywords: lawyer, professional competence, competency, structure, factorial and criterial model, factor, criterion.

\section{Introduction}

Reforms taking place at the modern stage of the development of Ukraine require independent, responsible, creative professionals capable of efficient interaction in performing social and economic tasks under unstable conditions. A traditional approach to education as a means of transferring experience of previous generations to the new ones does not meet modern social requirements. All this conditions the competence approach implementation into the educational process of higher educational institutions. The necessity of transferring to the competence format of studying requires teaching staff to reconsider the goals and results of educational activities of universities and their description through competences and competency [6, p. 72].

However, according to I. Drach, the issue of implementing competence-based approach into the educational system is complicated by the uncertainty and ambiguity of "competence" and "professional competence" terms, though they become more and more widespread and are used in the processes of discussing the improvement of quality of education [5].

P. Heiger distinguishes the following stages of the development of "competence" concept:

- the first one (1960-1970) is a behavioristic interpretation of the term according to which it is a simple demonstration of activities in terms of performing certain fragments of tasks aimed at the development of skills;

- the second one (1970-1990) provides the understanding of competences as skills of general nature which determine the essence of future activity;

- according to the third one (starting from 1990) competences require the elements of execution and pos- session of certain intellectual, moral and social qualities [13].

In the Law of Ukraine "On higher education" dated 2012 [2] competence is interpreted as dynamic set of knowledge, skills, ways of thinking, views, values, and other personal qualities which determine personal ability for socialization, performance of professional and/or further educational activities.

According to the Law of Ukraine "On higher education" dated 2014 [1] competence is defined in a more extensive way: combination of knowledge, skills, ways of thinking, professional and social qualities, moral and ethical values which define person's ability to perform professional and/or further educational activities and is a result of studying at a certain level of higher education.

The carried out analysis of scientific sources shows that there are lots of interpretations of this phenomenon. In our research, we share I. Drach's opinion that competence is complex integrated characteristics which provides person's ability for his/her own potential fulfillment (knowledge, skills, experience, personal qualities) for the successful activity in professional and social spheres, understanding social value and responsibility of its results, and the necessity for continuous self-development [5].

As a rule, this phenomenon is considered in terms of work, professionalism, professional skills, qualification, which stipulates the appearance of the term "professional competence". Most researchers use it in the extended sense, as a synonym to the word "competency" and understand it as a multi-component phenomenon which provides the mastering of all professional and extra- 
professional competences which is the key for effective activity [5].

It should be noted that in scientific psychopedagogical literature "legal competence" is studied alongside "professional competence of a lawyer" concept. According to O. Yehorova and O. Zinchenko, the concept of legal competence is used when dealing with professional training of university students of non-legal fields, while "professional competence of a lawyer" is used in terms of higher legal education. The scientists believe that the structure of future lawyers' professional competence combines personal and professional aspects through the combination of interrelated competencies, conditioned by the level of theoretical and practical professional skills: general competencies (informational, reflexive, etc.) and professional (legal, social, communicative, etc.).

In the scientific work of N. Suddenkova, professional competence of future lawyers is regarded as integral characteristics of business and personal qualities which reflect the level of knowledge, skills and experience, sufficient for the achievement of the desired goal, as well as moral position and attitude towards work and oneself $[11$, p. 10].

I. Ivashkevych believes that professional competence of future lawyers consists of the following components: motivation and goal, cognitive, social, axiological and autopsychological [8].

E. Nigmatullina understands it as an integrative personal quality being a set of interrelated legal, information, socio-communicative, reflexive and management competences and processional creativity [9, p.12].

V. Tymofieiev suggests "professional legal competence" term which is explained by the fact that legal competence is a component of both general and professional competence, without which professional development of a lawyer is impossible. It is considered by him as a complex phenomenon which manifests itself in professionally significant qualities, as well as the set of professional knowledge about legal phenomena and legal behavior standards, skills of using them in legal activities with the aim to address professional challenges. It consists of the following components: motivational, cognitive, axiological, reflexive, and communicative [12].

Therefore, in our opinion, professional competence of a lawyer is a dynamic system phenomenon which reflects person's ability to perform legal activities on the basis of integration of theoretical knowledge, practical skills, experience, values and personal qualities. The definition of competence as a system phenomenon allows to design its ideal model and measuring instruments [7].

The scientific literature review shows the researchers' interest to the issue of professional training of future lawyers in terms of competence-based approach. However, despite its relevance there is no clear determination of the specificity and essence of the development of future lawyers' competence in modern pedagogy. Thus, taking into account the above mentioned we believe that this issue is quite significant both in theoretical and experimental planes.

The paper aims to present the developed factorial and criterial model of the development of future lawyers' professional competence.

The following tasks have been set:

- based on theoretical analysis of literature summarize main characteristics of professional competence of a lawyer;

- single its structural components in terms of functional approach;

- present factor and criterial model of lawyers' professional competence.

Characteristics and Structural Components of Lawyer's Professional Competence

The generalization of the results of theoretical and methodological analysis of the concept of lawyer's professional competence has helped us to distinguish the following characteristics: it is a dynamic system formation; it reflects lawyer's ability to perform his/her professional duties properly; it is formed as a result of professional training; reflects values, in particular attitude towards work and the professional environment.

In order to distinguish the structural components of lawyer's professional competence we use the competences hierarchy suggested by I. Drach [5], which has the threelevel structure and involves key, general and special competences.

Key competences are the basis for the formation of general and special ones, and the general competences - for special ones. The key competences provide an opportunity to act in different spheres of social life efficiently. General competences reflect the specificity of lawyer's occupation, they are necessary for carrying out professional duties and at the same time they realize key competences. Special competences show the specificity of a certain type of lawyer's work, their realization is conditioned by general and key competences. Profession of a lawyer is a set of these competences. The generalization of scientific sources provides an opportunity to distinguish the following key competences of a lawyer: civil, general cultural, social, purposeful development, and responsibility.

In order to outline general and special professional competence from the standpoint of the functional approach it is appropriate to review the essence of the structural components of the profession of a lawyer. V. Romanov distinguishes four main substructures of legal activities: cognitive, organizational, educational, and communicative [10, p. 311].

The review of scientists' works $[6 ; 9 ; 12]$ has made it possible to define the following general competences: legal, administrative, functional, communication, educational, and scientific.

We believe that special theoretical and special functional competences are a part of special competences.

Research Methods and Results Obtained

The development of qualimetric model of lawyer's professional competence was performed according to the 
methodological principles of modern qualimetry and stages described in the scientific work of I. Annienkiva [3]. It has been designed on the basis of the described three-level model of professional competence of a lawyer. Key, general and special professional competences make its factors. The most significant competences defined as the criteria of factorial and criterial model are designated at every level.

The experiment involved 14 second-year students studying at the Faculty of Crime Investigators and the Faculty of Advocacy. Our aim was to investigate the views of junior students concerning the structure of lawyers' professional competence and then to compare them with the ideas of graduates and lecturers.
The calculation of weighting coefficient for every factor and criterion was performed on the basis of students' opinions by means of Delphi method.

Stage 1 involved the creation of expert commission. Number of factors was 5, number of experts -14 .

Stage 2. Collection of experts' opinions by means of questionnaires. The assessment of factors' measure of significance was performed by the experts by means of rank ordering assignment. The factor which gets the highest score by the expert, is assigned 1 rank. On the basis of the questionnaire results an integrated matrix of ranks is composed (Tables 1,2).

Integrated matrix of ranks

\begin{tabular}{|l|c|c|c|c|c|c|c|c|c|c|c|c|c|c|}
\hline \hline Competence & 1 & 2 & 3 & 4 & 5 & 6 & 7 & 8 & 9 & 10 & 11 & 12 & 13 & 14 \\
\hline Civil & & & & & & & & & & & & & & \\
\hline Social & 1 & 1 & 1 & 1 & 2 & 1 & 1 & 1 & 1 & 1 & 2 & 1 & 1 & 1 \\
\hline General cultural & 3 & 4 & 3 & 4 & 3 & 2 & 5 & 3 & 4 & 5 & 3 & 4 & 2 & 3 \\
\hline Purposeful development & 4 & 3 & 4 & 3 & 4 & 5 & 4 & 4 & 3 & 4 & 4 & 3 & 5 & 4 \\
\hline Responsibility & 5 & 5 & 5 & 5 & 5 & 4 & 2 & 5 & 5 & 2 & 5 & 5 & 4 & 5 \\
\hline$\Sigma$ of ranks & 15 & 15 & 15 & 15 & 15 & 15 & 15 & 15 & 15 & 15 & 15 & 15 & 15 & 15 \\
\hline
\end{tabular}

Integrated matrix of ranks

\begin{tabular}{|c|c|c|c|c|}
\hline Competence & $\begin{array}{c}\text { Sum of } \\
\text { ranks }\end{array}$ & $\begin{array}{c}\text { Departure from mean } \\
\text { value }\end{array}$ & $\begin{array}{c}\text { Squared departure from } \\
\text { mean value }\end{array}$ & $\begin{array}{c}\text { Weight coeffi- } \\
\text { cient }\end{array}$ \\
\hline Social & 16 & -26 & 676 & 0.3857 \\
\hline Civil & 30 & -12 & 144 & 0.2857 \\
\hline General cultural & 48 & 6 & 36 & 0.1571 \\
\hline Purposeful development & 54 & 12 & 144 & 0.1143 \\
\hline Responsibility & 62 & 20 & 400 & 0.05714 \\
\hline$\Sigma$ & 210 & & 1400 & 1 \\
\hline
\end{tabular}

Stage 3. Checking the correctness of composing the matrix based on measuring the control sum according to the formula (1):

$$
\sum x_{i j}=\frac{(1+n) n}{2}=\frac{(1+5) \times 5}{2}=15
$$

The sums in the matrix columns and control sum are equal, which means that the matrix is composed correctly.

Stage 4. Analysis of significance of the factors studied (Table 2).

Stage 5. Assessment of the experts' opinions dimension of agreement. The concordance coefficients have been calculated according to the formula:

$$
\begin{aligned}
W= & \frac{125}{m^{2}\left(n^{3}-n\right)} ; \\
& \text { where } S=1400, \mathrm{n}=5, \mathrm{~m}=14 .
\end{aligned}
$$

$\mathrm{W}=0.714$ is indicative of the high dimension of agreement.
Stage 6. Assessment of concordance coefficient significance. In order to do this, we use the Pearson's chisquared test and measure according to the formula:

(1) $\chi^{2}=n(m-1) W$

We compare the calculated $\chi^{2}$ with the table values for the number of degrees of freedom $\mathrm{K}=\mathrm{n}-1=6-1=5$, $\alpha$ $=0.05$. Considering the fact $\chi^{2}=28,55 \geq$ of the table (11.07050), then $\mathrm{W}=0.716$ - is not an accidental value and the results obtained can be used in further studies.

Stage 7. The calculation of weight coefficients of the studied factors based on transformation of the survey matrix into the matrix of transformed ranks according to the formula: $\mathrm{s}_{\mathrm{ij}}=\mathrm{x}_{\max }-\mathrm{x}_{\mathrm{ij}}$, where $\mathrm{x}_{\max }=6$.

The measured weight coefficients are presented in Table 2. In the same way we calculated weight coefficients both for general competences and the levels of competence. In order to automatize the calculations, we used Excel program. 
Based on the research outcomes we have designed a factorial and criterial model of professional competence of a lawyer (Table 3).

The assessment scale of the level of lawyer's professional competence within 1 point has the gradation as follows: up to 0.5 - low level of professional competence, 0.51-0.64 - satisfactory level, 0.65-0.84 - sufficient level, 0.85-1.00 - high level.

Qualimetric model of lawyer's professional competence

\begin{tabular}{|c|c|c|c|}
\hline Factor & Weight & Criteria & Weight \\
\hline \multirow[t]{5}{*}{ 1. Key competences } & \multirow[t]{5}{*}{0.29} & 1. Civil & 0.38 \\
\hline & & 2. Social & 0.29 \\
\hline & & 3. General cultural & 0.16 \\
\hline & & 4. Purposeful development & 0.11 \\
\hline & & 5. Responsibility & 0.06 \\
\hline \multirow[t]{6}{*}{ 2. General competences } & \multirow[t]{6}{*}{0.61} & 6. Legal & 0.29 \\
\hline & & 7. Functional & 0.20 \\
\hline & & 8. Administrative & 0.29 \\
\hline & & 9. Communicative & 0.15 \\
\hline & & 10. Educational & 0.02 \\
\hline & & 11. Scientific & 0.06 \\
\hline \multirow[t]{2}{*}{ 3. Special competences } & \multirow[t]{2}{*}{0.10} & 12. Special theoretical & 0.39 \\
\hline & & 13. Special functional & 0.61 \\
\hline
\end{tabular}

The main advantage of the designed model as compared to other available techniques of assessing competences is an integral image of professional competence of a lawyer as a system of interrelated components which can be considered as a certain standard.

\section{Conclusion}

As a result of the carried out research it has been found that professional competence of a lawyer is a dynamic system formation which reflects the level of the efficiency of professional duties fulfillment, skills of coping with professional problems. Based on the scientific sources review the content of professional competence of a lawyer has been defined. It has three-level

\section{REFERENCES}

1. Zakon Ukrainy "Pro vyshchu osvitu» vid 01.07.2014r. [Law of Ukraine "On higher education" dated June, 1, 2014]. Retrieved from: http://zakon4.rada.gov.ua/laws/show/1556-18/page [in Ukrainian].

2. Zakon Ukrainy «Pro osvitu» vid 05.09.2017 r. [Law of Ukraine "On higher education" dated September, 5, 2017]. Retrieved from: http://zakon4.rada.gov.ua/laws/show/1556-18/page [in Ukrainian].

3. Annienkova, I. P. (2016). Teoriia i metodyka monitorynhu yakosti profesiinoi diialnosti naukovopedahohichnykh pratsivnykiv vyshchykh navchalnykh zakladiv [Theory and methods of monitoring quality of professional activity of teaching staff of higher educational institutions]. Candidate's thesis. Kyiv [in Ukrainian].

4. Hura, O. I. (2008). Teoretyko-metodolohichni osnovy formuvannia psykholoho-pedahohichnoi kompetentnosti vykladacha vyshchoho navchalnoho hierarchical structure (the $1^{\text {st }}$ level involves key competences, the $2^{\text {nd }}$ one - general competences, and the $3^{\text {rd }}$ one - special competences). The suggested factorial and criterial model of lawyer's professional competence generalizes the peculiarities of the occupation of a lawyer. Based on such a structure one can expand and concretize the requirements to any kind of legal activities.

We plan to focus our further research work on coordination of criteria of professional competence maturity based on studying graduates' and teachers' opinions, as well as to develop methodical support of carrying out the assessment.

zakladu v umovakh mahistratury [Theoretical and methodological bases of formation of university teacher's psycho-pedagogical competence]. Doctor's thesis. Zaporizhzhia [in Ukrainian].

5. Drach, I. I. (2013). Upravlinnia formuvanniam profesiinoi kompetentnosti mahistrantiv pedahohiky vyshchoi shkoly: teoretyko-metodychni zasady. Monohrafiia [Management of the formation of professional competence of master-degree students majoring in pedagogical specialties: monograph]. Kyiv: «DoradoDruk» [in Ukrainian].

6. Ehorova, O. A. (2016). Pravovaia kompetentnost studentov neiurydycheskykh spetsyalnostei y professyonalnaia kompetentnost studentov - budushchykh yurystov [Legal competence of non-legal specialties students and professional competence of future lawyers]. Vestnyk YuUrHU. Seryia "Obrazovanye. Pedahohycheskye nauky». - Bulletin of Law university. Pedagogy 4, 72-80. DOI: 10.14529/ped 160410 
7. Yelnykova, H. V. (2010). Kompetentnisnyi pidkhid do modeliuvannia profesiinoi diialnosti kerivnyka vyshchoho navchalnoho zakladu [Competence-based approach to modelling professional activity of educational institutions' heads]. Teoriia ta metodyka upravlinnia osvitoiu - Theory and methods of education management, 4. Retrieved from: http://tme.umo.edu.ua/ docs/4/ 10elneel.pdf. Kyiv [in Ukrainian].

8. Ivashkevych, I. V. (2016). Funktsionalnyi pidkhid do vyznachennia zmistu ta struktury profesiinoi kompetentnosti maibutnikh yurystiv [Functional approach to determination of content and structure of future lawyers' professional competence]. Problemy suchasnoi psykholohii - Challenges of modern psychology, 32, 167180 [in Ukrainian].

9. Nigmatullina, E. N. (2014). Pedagogicheskie usloviya formirovaniya professionalnoi kompetentnosti yurista po napravleniyu podgotovki «Mezhdunarodnye otnosheniya» [Pedagogical conditions of forming professional competence of lawyers in the specialty "International affairs"]. Extended abstract of candidate's thesis. Ioshkar-Ola : Bashkir. gos. un-t [in Russian].

\section{ЛІТЕРАТУРА}

1. Закон України «Про вищу освіту» від 01.07.2014p. № 1556-VII [Електронний ресурс]. Режим доступу

http://zakon4.rada.gov.ua/laws/show/1556-18/page.

2. Закон України «Про освіту» від 05.09.2017 р. № 2145-VIII [Електронний ресурс]. - Режим доступу : http://zakon4.rada.gov.ua/laws/show/1556-18/page.

3. Аннєнкова І.П. Теорія і методика моніторингу якості професійної діяльності науковопедагогічних працівників вищих навчальних закладів : дис... д-ра пед.наук : 13.00.06 / І.П. Аннєнкова. Київ, 2016. - 505 с.

4. Гура O.I. Теоретико-методологічні основи формування психолого-педагогічної компетентності викладача вищого навчального закладу в умовах магістратури : дис... д-ра пед.наук : 13.00.04 / O.I. Гура. Запоріжжя, 2008. - 752 с.

5. Драч I. І. Управління формуванням професійної компетентності магістрантів педагогіки вищої школи: теоретико-методичні засади. Монографія / I. I. Драч. - К. : «Дорадо-Друк», 2013. - 456 с.

6. Егорова О.А. Правовая компетентность студентов неюридических специальностей и профессиональная компетентность студентов - будущих юристов / О.А. Егорова, Е.Н. Зинченко // Вестник ЮУрГУ. Серия «Образование. Педагогические науки». - 2016. - T. 8, № 4. - C. 72-80. DOI: 10.14529/ped160410

7. Єльникова Г.В. Компетентнісний підхід до моделювання професійної діяльності керівника вищого навчального закладу / Г. В. Сльникова // Теорія та методика управління освітою. [Електронний ресурс]. - Режим доступу : http://tme.umo.edu.ua/ docs/4/
10. Romanov, V. V. (2000). Yuridicheskaya psikhologiya [Law psychology]. Moscow: Iurist [in Russian].

11. Suddenkova, N. V. (2007). Formirovanie professionalnoi kompetentnosti spetsialista pravovoi sfery v SSUZ [Formation of professional competence of a legal expert]. Extended abstract of candidate's thesis. Kazan: In-t pedagogiki i psikhologii prof. obrazovaniia Ros. akad. obrazovaniia [in Russian].

12. Tymofieiev, V. A. (2014). Sutnist ta struktura profesiino-pravovoi kompetentnosti maibutnikh yurystiv u vyshchykh profesiinykh navchalnykh zakladakh [Essence and structure of professional legal competence of future lawyers at educational institutions]. Naukovi zapysky Kyivskoho universytetu turyzmu, ekonomiky i prava. Seriia: filosofski nauky - Scientific notes of Kyiv university of tourism, economy and law. Series: philosophic sciences, 17, 260270. Kyiv: KUTEP [in Ukrainian].

13. Hager, P. (1998). Is There a Cogent Philosophical Argument against Competence on Standarts? Philosophu of Education: Major Themes in the Analytic Tradition: Problems of Educational and Practices; Ed. by Paul Hirst and Patricia White, (Vol. 4), (pp. 399-415). Florence: Routledge [in English].

10elneel.pdf. - Київ, 2010. - № 4.

8. Івашкевич I.В. Функціональний підхід до визначення змісту та структури професійної компетентності майбутніх юристів / І.В. Івашкевич // Проблеми сучасної психології. - 2016. - Вип. 32 - С. 167-180.

9. Нигматуллина Э.Н. Педагогические условия формирования профессиональной компетентности юриста по направлению подготовки «Международные отношения»: автореф. дис. ... канд. пед. наук / Э.Н. Нигматуллина. - Йошкар-Ола : Башкир. гос. унт, 2014. -27 c.

10. Романов В.В. Юридическая психология / Владимир Владимирович Романов. - М. : Юрист, 2000. - 488 c.

11. Судденкова Н.В. Формирование профессиональной компетентности специалиста правовой сферы в ССУЗ : автореф. дис. ...канд. пед. наук / Н.В. Судденкова. - Казань : Ин-т педагогики и психологии проф. образования Рос. акад. образования, 2007. - 22 с.

12. Тимофєєв В. А. Сутність та структура професійно-правової компетентності майбутніх юристів у вищих професійних навчальних закладах. / В.А. Тимофєєв //Наукові записки Київського університету туризму, економіки і права. Серія: філософські науки. - К.: КУТЕП, 2014. - Випуск 17. - С.260-270.

13. Hager P. Is There a Cogent Philosophical Argument against Competence on Standarts? / P. Hager // Philosophu of Education: Major Themes in the Analytic Tradition: Problems of Educational and Practices; Ed. by Paul Hirst and Patricia White. Vol. 4. - Florence : Routledge, 1998. - P. 399-415. 
Наталія Іванівна Костова,

кандидат юридичних наук, дочент кафедри циивільного права, національний університет «Одеська юридична академія», вул. Академічна, 5, м. Одеса, Україна

\section{СТРУКТУРА ПРОФЕСІЙНОЇ КОМПЕТЕНТНОСТІ СТУДЕНТІВ-МАЙБУТНІХ ЮРИСТІВ}

Актуальність теми обумовлена запровадженням в освітній процес вищих навчальних закладів компетентнісного підходу, який вимагає переосмислення цілей и результатів освітньої діяльності вищих навчальних закладів та їх опису через компетентності и компетенції. Метою дослідно-експериментальної роботи було розроблення та обгрунтування факторно-критеріальної моделі професійної компетентності юриста. Було використано такі методи наукового пізнання: аналіз, факторно-критеріальне моделювання, метод Дельфі. Теоретичний аналіз наукових праць провідних вітчизняних та зарубіжних науковців 3 проблеми дослідження дозволив визначити основні характеристики професійної компетентності юриста: системність і динамічність, відображення здатності ефективно здійснювати професійну діяльність, ціннісних смислів; основний критерій відповідності рівня фахової підготовки вимогам професійної діяльності. Визначено зміст професійної компетентності юриста, що має трирівневу ієрархічну структуру: перший рівень складається 3 ключових компетентностей: громадянської, соціальної, цілеспрямованого саморозвитку; загальнокультурної, автономності і відповідальності; другий рівень містить загальнофахові компетентності: правову, управлінську, функціональні, комунікативну, виховну, загальнонаукову; третій рівень - спеціальні професійні компетентності: спеціально-теоретичну та спеціальнофункціональну компетентності. Зміст і структура професійної компетентності науково-педагогічного працівника вищої школи відображає основні функції та вимоги до його діяльності, знання, вміння й навички, соціально та професійно значущі якості особистості. На основі кваліметричного підходу розроблено факторнокритеріальну модель професійної компетентності юриста, в якій описані рівні і види компетентностей визначають фактори і критерії. Обчислено вагові коефіцієнти для кожного фактору та критерію. Особливістю цієї моделі є можливість адаптації до специфіки певного виду юридичної діяльності, що забезпечує тї варіативність.

Ключові слова: юрист, професійна компетентність, компетенція, структура, факторно-критеріальна модель, фактор, критерій.

Reviewed by Doctor of Pedagogy, prof. I. Buzhyna

Submitted onn June, 23, 2017 